\title{
METODE TRANSLITERASI UNTUK MENINGKATKAN KEMAMPUAN MEMBACA AKSARA JAWA DI PROGRAM STUDI PENDIDIKAN GURU SEKOLAH DASAR
}

\section{TRANSLITERATION METHOD TO IMPROVE THE READING SKILLS READING JAVANESE SCRIPT IN PRIMARY SCHOOL TEACHER EDUCATION STUDY PROGRAM}

\author{
Biya Ebi Praheto ${ }^{1}$, Felix Baskara Bhakti Utomo ${ }^{2}$ \\ 1,2Program Studi Pendidikan Guru Sekolah Dasar \\ ${ }^{1,2}$ Universitas Sarjanawiyata Tamansiswa Yogyakarta \\ biya.ebi@ustjogja.ac.id ${ }^{1}$
}

\begin{abstract}
This study aims to improve the reading skills of Javanese script students at Primary School Teacher Educatoion Study Program of Sarjanawiyata Tamansiswa University through the implementation of the transliteration method. This research is a classroom action research. The subjects of this study were students in grade $3 A$. As for the object is the ability to read Javanese script. Research data obtained through observation techniques, documents, and tests. The results showed an increase in the ability to read Javanese script in students. Pre-cycle results showed an average value of 46.84, increased in cycle 1 to 76.4 and 85.6 in cycle 2. Furthermore, classical completeness in prasiklus by $41.03 \%$ increased to $64.1 \%$ in cycles 1 and $87,2 \%$ in cycle 2.
\end{abstract}

Keywords: Javanese Script, Primary School Teacher Education, Reading, Student, Transliteration Method.

\begin{abstract}
Abstrak
Penelitian ini bertujuan meningkatkan kemampuan membaca aksara Jawa mahasiswa Program Studi PGSD UST melalui implementasi metode transliterasi. Penelitian ini merupakan penelitian tindakan kelas yang dilakukan di Program Studi PGSD Universitas Sarjanawiyata Tamansiswa Yogyakarta. Subjek penelitian ini yaitu mahasiswa kelas 3A. Adapun objek penelitiannya yaitu kemampuan membaca aksara Jawa. Data penelitian diperoleh melalui teknik observasi, dokumen, dan tes. Kemudian, teknik analisis data yang digunakan merupakan deskriptif kualitatif. Hasil penelitian menunjukkan terjadinya peningkatan kemampuan membaca aksara Jawa pada mahasiswa. Hal tersebut ditunjukkan dari hasil kegiatan prasiklus hingga siklus II. Hasil prasiklus menunjukkan rata-rata nilai sebesar 46,84, meningkat pada siklus 1 menjadi 76,4 dan 85,6 pada siklus 2. Selanjutnya ketuntasan klasikal pada prasiklus sebesar $41,03 \%$ meningkat menjadi $64,1 \%$ pada siklus 1 dan $87,2 \%$ pada siklus 2 .
\end{abstract}

Kata Kunci: Aksara Jawa, Membaca, Metode Trasliterasi, PGSD, Siswa.

\section{PENDAHULUAN}

Program Studi Pendidikan Guru Sekolah Dasar (PGSD) merupakan program studi yang menyiapkan para calon guru sekolah dasar. Guru sekolah dasar adalah guru kelas yang harus menguasai berbagai bidang ilmu, tidak terkecuali bahasa Jawa. Bahasa Jawa merupakan salah satu muatan lokal yang diajarkan di sekolah dasar di daerah Jawa seperti D.I. Yogyakarta, Jawa Tengah, dan Jawa Timur. Oleh sebab itu, di Program
Studi PGSD UST muncul dua mata kuliah terkait bahasa Jawa yaitu mata kuliah Keterampilan Berbahasa Jawa dan mata kuliah Bahasa dan Sastra Jawa.

Salah satu materi yang dianggap sulit yaitu aksara Jawa pada mata kuliah Keterampilan Berbahasa Jawa. Pada dasarnya kesulitan tersebut tidak hanya dirasakan oleh mahasiswa Program Studi PGSD saja, tetapi juga bagi siswa sekolah dasar. Oleh sebab itu, salah satu cara yang 
Biya Ebi Praheto dan Felix Baskara Bhakti Utomo
Metode Transliterasi untuk Meningkatkan

Kemampuan Membaca Aksara Jawa di

Program Studi Pendidikan Guru Sekolah

Dasar dapat dilakukan terkait penguasaan membaca dan menulis aksara Jawa di sekolah adalah dengan mencetak lulusan Program Studi PGSD yang mampu membaca aksara Jawa dengan baik, sehingga dapat mengajarkannya dengan baik pula di sekolah dasar. Pada pelaksanaan pembelajaran aksara Jawa terdapat beberapa kendala diantaranya yaitu kesulitan mahasiswa untuk memahami serta menghafal bentuk aksara Jawa. Permasalahan tersebut, menyebabkan mahasiswa kesulitan membaca aksara Jawa seperti tidak dapat membedakan bentuk huruf misalnya beberapa huruf yang mirip, seperti aksara sa dan $d a$, ha dan la, ca dan $w a$, serta masih banyak lagi aksara Jawa yang secara visual memiliki kemiripan bentuk [1].

Permasalahan yang muncul pada pembelajaran aksara Jawa dapat disebabkan oleh beberapa faktor. Faktor tersebut diantaranya yaitu kurang tepatnya pemilihan metode dan media pembelajaran, rendahnya motivasi belajar aksara Jawa, serta materi pembelajaran yang cukup sulit. Selama ini, pembelajaran hanya berfokus pada bunyi aksara Jawa sehingga berdampak pada kesulitan mahasiswa untuk memahami bentuk atau simbol aksara Jawa yang berdampak pada rendahnya kemampuan membaca aksara Jawa. Membaca merupakan pengenalan simbol-simbol bahasa tulis yang merupakan stimulus yang membantu proses mengingat tentang apa yang dibaca, untuk membangun suatu pengertian melalui pengalaman yang telah dimiliki [2]. Selain itu, Ref. [3] juga menyatakan bahwa membaca merupakan aktivitas pencarian informasi melalui lambang-lambang tertulis. Di samping membaca merupakan aktivitas mengenal simbol juga merupakan aktivitas berbahasa yang bersifat reseptif karena dengan membaca seseorang dapat memperoleh informasi, pengetahuan, dan pengalaman baru [4]. Ref. [5] juga mengemukakan bahwa hakikat kegiatan membaca adalah memperoleh makna yang tepat. Oleh sebab itu, dalam kaitannya membaca aksara Jawa, mahasiswa akan kesulitan memperoleh makna dari suatu bacaan jika tidak mampu mengenal simbol bentuk aksara Jawa.

Melihat faktor penyebab dan permasalahan pembelajaran aksara Jawa, maka perlu diambil langkah penyelesaian yang strategis. Salah satu cara strategi dalam pembelajaran membaca aksara Jawa salah satunya yaitu menerapkan metode yang tepat dalam pembelajaran. Metode pembelajaran merupakan cara kerja yang bersistem untuk memudahkan pelaksanaan suatu kegiatan terutama kegiatan pembelajaran guna mencapai tujuan yang ditentukan [6]. Metode yang digunakan untuk mengatasi permasalahan pembelajaran aksara Jawa yaitu metode transliterasi. Onions dalam Ref. [7] menyebutkan bahwa transliterasi adalah suntingan yang disajikan dengan jenis tulisan lain. Senada dengan hal tersebut, Ref. [8] berpendapat bahwa transliterasi adalah penggantian jenis tulisan, huruf demi huruf dari satu abjad ke abjad yang lain. Selain itu, transliterasi dalam Kamus Istilah Ref. [9], didefinisikan sebagai pengubahan teks dari satu tulisan ke tulisan yang lain atau dapat disebut alih huruf atau alih aksara, misalnya dari huruf Jawa ke huruf Latin, dari huruf Sunda ke huruf Latin, dan sebagainya. Kemudian, Ref. [10] juga menyebutkan bahwa transliterasi merupakan pemindahan sistem penulisan suatu naskah ke dalam sistem penulisan yang lain. Selanjutnya, ada pula yang menyebutkan transliterasi adalah penggantian atau pengalihan huruf demi huruf dari abjad yang satu ke abjad yang lain [11]. Sehingga dapat dikatakan bahwa transliterasi didefinisikan sebagai pemindahan dari satu tulisan ke tulisan yang lain. Pada peneltian ini diterapkan metode transliterasi pada teksteks dalam majalah bahasa Jawa untuk digubah ke dalam teks berhuruf Jawa. Diharapkan dengan penerapan metode transliterasi, mahasiswa mampu dengan mudah untuk menghafalkan bentuk-bentuk 
Biya Ebi Praheto dan Felix Baskara Bhakti Utomo
Metode Transliterasi untuk Meningkatkan Kemampuan Membaca Aksara Jawa di Program Studi Pendidikan Guru Sekolah Dasar aksara Jawa sehingga mendukung terhadap penguasaan keterampilan membaca aksara Jawa.

\section{METODE PENELITIAN}

Penelitian ini merupakan penelitian tindakan kelas yang dilakukan dalam dua siklus. Setiap siklus meliputi empat tahap, yaitu perencanaan, tindakan, observasi/ interpretasi, dan refleksi. Subjek penelitian tindakan ini adalah mahasiswa semester 3 kelas 3A Program Studi Pendidikan Guru Sekolah Dasar (PGSD) Universitas Sarjanawiyata Tamansiswa Yogyakarta. Pemilihan kelas tersebut didasarkan pada kemampuan membaca aksara Jawa mahasiswa yang masih rendah dibandingkan dengan kelas lainnya. Adapun objek penelitiannya, yaitu kemampuan membaca aksara Jawa mahasiswa. Teknik yang digunakan untuk mengumpulkan data meliputi pengamatan atau observasi, kajian dokumen, dan tes. Teknik analisis data yang digunakan dalam penelitian ini adalah teknik deskripsi komparatif. Teknik ini digunakan untuk membandingkan hasil antar siklus. Peneliti membandingkan hasil sebelum penelitian dengan hasil pada akhir setiap siklus. Indikator kinerja yang digunakan untuk menentukan keberhasilan dari implementasi metode transliterasi dalam pembelajaran membaca aksara Jawa, yaitu jika rata-rata kelas di atas nilai KKM (Kriteria Ketuntasan Minimal) sebesar 75 dan minimal $80 \%$ mahasiswa mampu mencapai nilai batas ketuntasan.

\section{HASIL DAN PEMBAHASAN}

Metode transliterasi dilakukan dengan mengubah teks berhuruf Latin pada bacaanbacaan majalah bahasa Jawa menjadi bacaan berhuruf atau beraksara Jawa. Hasil tindakan prasiklus hingga siklus II mengalami peningkatan hingga mencapai indikator penelitian yang direncanakan. Perbandingan hasil kemampuan membaca aksara Jawa antar siklus dapat dilihat sebagai berikut.

Tabel 1. Perbandingan Hasil antar Siklus

\begin{tabular}{|c|c|c|c|c|c|c|}
\hline \multirow{2}{*}{$\begin{array}{c}\text { Uraian } \\
\text { Pencapaian Hasil }\end{array}$} & \multicolumn{2}{|c|}{ Prasiklus } & \multicolumn{2}{|c|}{ Siklus I } & \multicolumn{2}{|c|}{ Siklus II } \\
\hline & $\sum_{\text {Mahasisw }}$ & $\%$ & $\sum_{\text {Mahasis }}^{\sum}$ & $\%$ & $\sum_{\text {Mahasis }}^{\sum}$ & $\%$ \\
\hline $\begin{array}{l}\text { Siswa mendapat } \\
\text { nilai }<75\end{array}$ & 23 & $58,97 \%$ & 14 & $35,9 \%$ & 5 & $12,8 \%$ \\
\hline $\begin{array}{l}\text { Siswa mendapat } \\
\text { nilai } \geq 75\end{array}$ & 16 & $41,03 \%$ & 25 & $64,1 \%$ & 34 & $87,2 \%$ \\
\hline Rerata & \multicolumn{2}{|c|}{46,84} & \multicolumn{2}{|c|}{76,4} & \multicolumn{2}{|c|}{85,6} \\
\hline $\begin{array}{l}\text { Ketuntasan } \\
\text { Klasikal }\end{array}$ & \multicolumn{2}{|c|}{$41,03 \%$} & \multicolumn{2}{|c|}{$64,1 \%$} & \multicolumn{2}{|c|}{$87,2 \%$} \\
\hline
\end{tabular}

Berdasarkan tabel 1 dapat diketahui terjadinya peningkatan yang cukup signifikan pada tindakan prasiklus hingga siklus II. Dapat diketahui bahwa nilai ratarata kelas pada prasiklus hanya mencapai 46,84 dan meningkat menjadi 76,4 pada siklus I, serta meningkat kembali pada siklus II menjadi 85,6. Peningkatan tersebut juga terjadi pada presentase ketuntasan klasikal, dapat diketahu pada prasiklus ketuntasan klasikal hanya mencapai $41,03 \%$ dan meningkat menjadi $64,1 \%$ pada siklus I, serta meningkat kembali menjadi $87,2 \%$ pada siklus II. Perbandingan hasil tiap siklus dalam bentuk diagram dapat dilihat sebagai berikut. 
Biya Ebi Praheto dan Felix Baskara Bhakti Utomo
Metode Transliterasi untuk Meningkatkan

Kemampuan Membaca Aksara Jawa di

Program Studi Pendidikan Guru Sekolah

Dasar

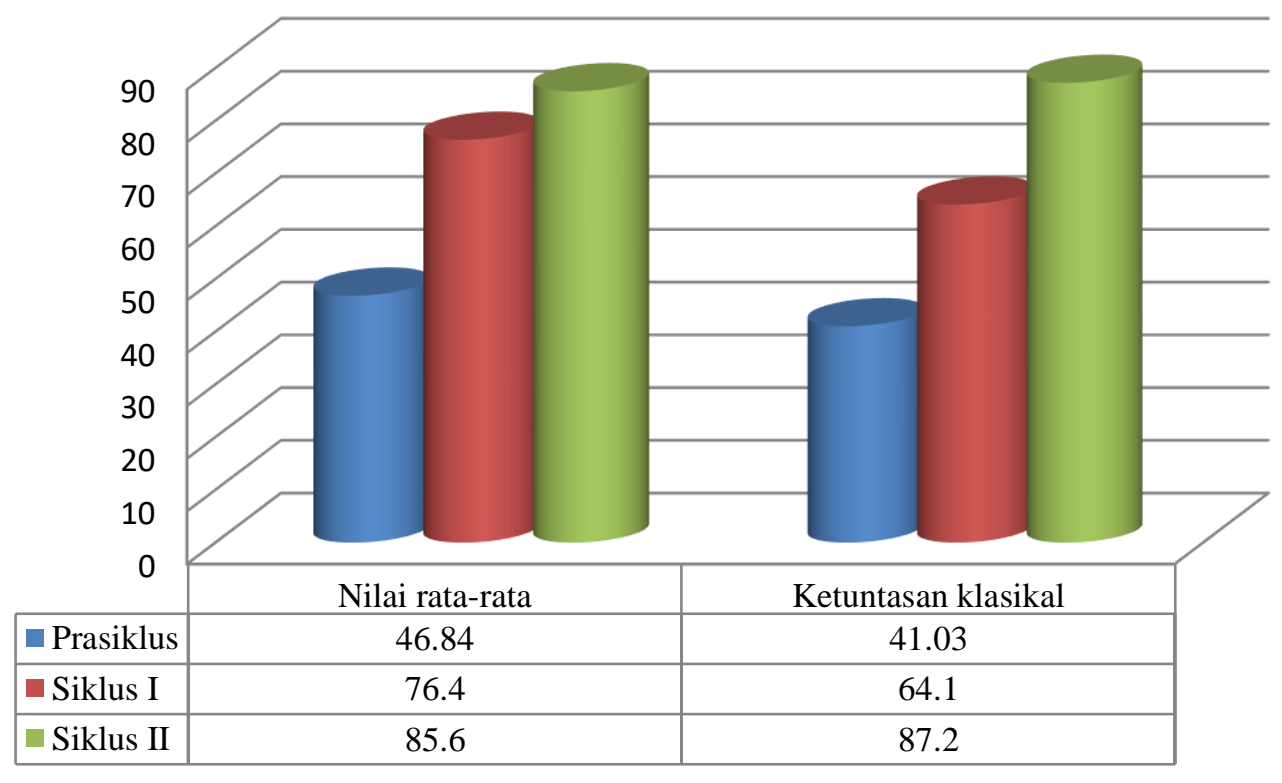

Gambar 1. Diagram Perbandingan Hasil Antar Siklus

Pembelajaran keterampilan bahasa Jawa pada materi aksara Jawa masih terdapat kendala. Salah satunya yaitu mahasiswa sulit untuk menghafalkan bentuk aksara Jawa. Melihat hal tersebut, inovasi dalam pembelajaran menjadi hal yang sangat penting untuk mengatasi permasalahan dalam pembelajaran [11]. Oleh sebab itu, diterapkan metode transliterasi untuk memudahkan mahasiswa dalam meghafalkan bentuk aksara Jawa. Sebelum diterapkan metode transliterasi, mahasiswa masih kesulitan untuk menghafalkan bentuk aksara Jawa. Hal tersebut berpengaruh pada kemampuan membaca aksara Jawa mahasiswa. Pada kegiatan prasiklus dapat diketahui bahwa hanya ada 16 mahasiswa yang sudah mencapai nilai ketuntasan minimal, sedangkan sisanya 23 mahasiswa belum mencapai nilai ketuntasan minimal. Selain itu, nilai rata-rata kelas hanya mencapai 46,84 dengan ketuntasan klasikal 41,03\%. Berdasarkan hasil refleksi pada prasiklus, rendahnya nilai siswa tersebut juga dikarenakan bentuk aksara Jawa yang memiliki kemiripan bentuk satu sama lain sehingga mahasiswa sering mengalami kesulitan membedakan bentuk aksara Jawa.
Melihat hal tersebut maka diterapkan metode transliterasi untuk meningkatkan kemampuan membaca aksara Jawa mahasiswa, terutama di Program Studi Pendidikan Guru Sekolah Dasar Universitas Sarjanawiyata Tamansiswa. Aksara Jawa menjadi bagian dari pembelajaran bahasa Jawa yang diajarkan di Program Studi PGSD. Metode transliterasi yang diterapkan dilakukan secara bertahap dari tingkat kesulitan yang rendah hingga tingkat kesulitan yang tinggi. Dan hal tersebut tampak pada uraian di setiap siklus berikut yaitu siklus 1 dan siklus II.

Setelah kegiatan prasiklus, tindakan selanjutnya yaitu tindakan siklus I dan siklus II. Dalam pembelajaran siklus I maupun siklus II diterapkan metode transliterasi yaitu mahasiswa menyalin teks latin ke dalam teks berhuruf Jawa. Proses pembelajaran tersebut diawali dengan mahasiswa menyalin aksara Jawa secara berulang-ulang. Selanjutnya, mahasiswa diminta mencari teks di dalam majalah bahasa Jawa dan menyalinnya ke dalam teks berhuruf Jawa. Ketika proses menyalin tersebut, mahasiswa diperbolehkan melihat bentuk contoh. Hal tersebut secara berkala 
Biya Ebi Praheto dan Felix Baskara Bhakti Utomo
Metode Transliterasi untuk Meningkatkan

Kemampuan Membaca Aksara Jawa di

Program Studi Pendidikan Guru Sekolah

Dasar dapat menjadikan mahasiswa menjadi hafal bentuk-bentuk aksara Jawa. Disisi lain mahasiswa secara berkelompok juga diberi tugas untuk menyalin novel berbahasa Jawa menjadi novel yang betuliskan dengan aksara Jawa. Pengalihan bentuk huruf latin menjadi aksara Jawa tersebut disebut dengan transliterasi.

Metode transliterasi yang diterapkan berdampak positif dan mampu meningkatkan kemampuan membaca aksara Jawa secara signifikan. Hal tersebut dapat dilihat adanya peningkatan kemampuan membaca aksara Jawa yang ditunjukkan dari nilai rata-rata pda siklus I menjadi 76,4 dengan ketuntasan klasikal sebesar $64,1 \%$ dan mengalami peningkatan lagi pada siklus II menjadi 85,6 untuk nilai rata-rata kelas dengan ketuntasan klasikal sebesar 87,2. Proses transliterasi yang dilakukan oleh mahasiswa secara tidak langsung menjadikan mahasiswa semakin hafal terhadap bentuk-bentuk aksara Jawa. Hafalnya mahasiswa terhadap bentuk-bentuk aksara Jawa tersebut sangat berpengaruh terhadap kemampuan membaca aksara Jawa, sehingga setelah diterapkan metode transliterasi dalam pembelajaran, kemapuan membaca aksara Jawa mahasiswa dapat meningkat dengan signifikan.

\section{KESIMPULAN}

Metode transliterasi sangat tepat untuk diterapkan dalam pembelajaran membaca maupun menulis aksara Jawa. Hal tersebut dikarenakan, dengan penerpan metode transliterasi mahasiswa lebih mudah untuk menghfalkan bentuk aksara Jawa. Berdasarkan hasil penelitian pada tahap prasiklus hingga siklus II, dapat disimpulkan bahwa terjadi peningkatan kemampuan membaca aksara Jawa yang signifikan. Hasil pada prasiklus menunjukkan rata-rata nilai sebesar 46,84 dengan ketuntasan klasikal sebesar $41,03 \%$ dan meningkat pada siklus 1 dengan nilai rata-rata klasikal menjadi 76,4 dengan ketuntasan klasikal sebesar $64,1 \%$. Kemudian, meningkat kembali pada siklus II yaitu nilai rata-rata kelas meenjadi 85,6 dengan ketuntasan klasikal mencapai 87,2\%.

\section{DAFTAR PUSTAKA}

[1]. Praheto, Biya Ebi. 2013. Penerapan Quantum Learning dengan Media Permainan Puzzle untuk Meningkatkan Kemampuan Membaca Aksara Jawa pada Siswa Kelas 3B SD Negeri 1 Wangon Kab. Banyumas. Tesis. Universitas Sebelas Maret Surakarta.

[2]. Abdurrahman, Mulyono. 1999. Pendidikan bagi Anak Berkesulitan Belajar. PT Rineka Cipta: Jakarta.

[3]. Ahmad, Listiyanto. 2010. Speed Reading: Teknik dan Metode Membaca Cepat. A Plus Books: Yogyakarta.

[4]. Nurgiyantoro, Burhan.1988. Penilaian dalam Pengajaran Bahasa dan Sastra. BPFE Yogyakarta: Yogyakarta.

[5]. Darmiyanti, Zuchdi. 2007. Strategi Meningkatkan Kemampuan Membaca. UNY Press: Yogyakarta.

[6]. Iskandarwassid, dan Sunendar, Dadang. 2013. Strategi Pembelajaran Bahasa. PT Remaja Rosdakarya: Bandung.

[7]. Darusuprapta. 1984. Beberapa Masalah Kebahasaan dalam Penelitian Naskah. Yogyakarta: Balai Penelitian Bahasa Pusat Pembinaan dan Pengembangan Bahasa Departemen Pendidikan dan Kebudayaan.

[8]. Baried, Baroroh. 1994. Pengantar Teori Filologi. Jakarta: Pusat Penelitian Bahasa Departemen Pendidikan dan Kebudayaan.

[9]. Baried, Baroroh. 1977. Kamus 
Biya Ebi Praheto dan Felix Baskara Bhakti Utomo
Metode Transliterasi untuk Meningkatkan Kemampuan Membaca Aksara Jawa di

Program Studi Pendidikan Guru Sekolah Dasar

Istilah Filologi. Yogyakarta:

Universitas Gajah Mada.

[10]. Sarinah. 2007. Transliterasi dan Analisis Makna Teks dalam Naskah Mar'atus Solikhah (Sebuah Tinjauan Filologi). Other thesis. University of Muhammadiyah Malang.

[10]. Djamaris, Edward. 2002. Metode Penelitian Filologi. CV Manasco: Jakarta.

[11]. Praheto, B.E., Andayani, Rohmadi, M., \& Wardani, N.E. 2020. The Effectiveness of Interactive Multimedia in Learning Indonesian Language Skills in Higher Education. Rupkatha Journal on Interdisciplinary Studies in Humanities. Vol. 12, No. 1, page 111. 